\title{
Model Prediksi Kebutuhan Air Bersih Berdasarkan Jumlah Penduduk di Kawasan Perkotaan Sentul City
}

\section{(A Model for Predicting Clean Water Need Base on Inhabitant Number in The} Urban Area Sentul City)

\footnotetext{
Asep Suheri ${ }^{1,2 *}$, Cecep Kusmana ${ }^{3}$, Moh. Yanuar J. Purwanto ${ }^{4}$, dan Yudi Setiawan ${ }^{5}$

${ }^{1}$ Mahasiswa S3 Program Studi Pengelolaan Sumberdaya Alam dan Lingkungan, Sekolah PascasarjanaInstitut Petanian Bogor, Bogor 16144, Indonesia.

${ }^{2}$ Program Studi Rekayasa Kehutanan, Sekolah Ilmu dan Teknologi Hayati-Institut Teknologi Bandung, Bandung 40132, Indonesia.

${ }^{3}$ Departemen Silvikultur, Fakultas Kehutanan-Institut Pertanian Bogor, Bogor 16144, Indonesia.

${ }^{4}$ Departemen Teknik Sipil dan Lingkungan, Fakultas Teknologi-Pertanian Institut Pertanian Bogor, Bogor 16144, Indonesia.

${ }^{5}$ Pusat Studi Lingkungan-Institut Pertanian Bogor, Bogor 16144, Indonesia.

*Penulis korespondensi: suheri.pslipb@gmail.com
}

Diterima: 06 Juli 2019

Disetujui: 09 Agustus 2019

\begin{abstract}
This research aims to create a model for predicting clean water need in the urban area Sentul City currently and next 30 (thirty years). To create the model, it is required data which are useful for forecasting the inhabitant number year to year. There are some general-used models for forecasting the inhabitant number, including to arithmatic, geometric, and least square method. The inhabitant number forecast in this research used an exponential method, as recommended in the Guidance of River Area Water Resource by Directorate General of Water Resource in 2001. The researcher used the software Stella 9.0.1 for simplifying the modeling process, projecting the inhabitant number, predicting the clean water need, and figuring the graphics. Besides this software, Excel programme was also used. According to data analysis result, the equation models to predict water need ( $\mathrm{m}^{3} /$ year) in Sentul City are stated as follows; for rural area inhabitants: YDn $=1927309(1+0.0303)^{n}$; for urban area inhabitants: YKn $=1$ $808940+217248 *_{n} ;$ and for total inhabitants: YSCn $=Y D n+Y K n$.
\end{abstract}

Keywords: inhabitant number, geomeric method, clean water need prediction

\section{PENDAHULUAN}

Kebutuhan air bersih tiap tahun pada umumnya mengalami peningkatan sedangkan ketersediaan air bersih semakin terbatas, dikarenakan semakin sempitnya daerah resapan, banyaknya pembangunan yang tidak memperhatikan keseimbangan alam, eksploitasi sumber air baku yang tidak memperhatikan kelestarian sumber air. Untuk antisipasi tidak terjadi krisis air, perlu menjaga dan melestarikan sumber air yang ada, efisiensi dalam penggunaan air serta pencarian alternatip sumber baru.
Sentul City merupakan kota mandiri di Kabupaten Bogor, yang dikembangkan oleh PT. Sentul City Tbk, mengembangkan kawasannya berkomitmen dengan prinsip green development melalui respon terhadap parameter city. Konsep eco-city diterapkan pada lanskap maupun bangunan. Kawasan ini dibangun sebagai kawasan perumahan, perdagangan, perkantoran, industri, pariwisata, serta fasilitas khusus (komersial).

Konsep pengembangan kawasan perkotaan Sentul City dituangkan dalam rencana induk (Masterplan Sentul City, 
2011) yang berkomitmen menjaga keseimbangan antara ruang terbangun dengan ruang terbuka, membagi kawasan menjadi dua area, yaitu area bangunan dan tutupan dengan area konservasi. Area konservasi yang direncanakan berupa hutan taman, taman bermain, dan danau buatan.

Ada dua karakteristik yang berbeda pada pertambahan penduduk di Sentul City, yaitu karakteristik kelompok penghuni yang telah menetap lama di desa dengan pertumbuhan penduduk secara alami sebesar 3,03\%, dan kelompok penghuni pendatang baru yang menghuni perumahan di kawasan perkotaan dengan perkiraan tambahan penduduk per tahun sebesar 4.960 jiwa (PT. Sukapura Graha Cemerlang 2018 dan Masterplan Sentul City 2011).

Terdapat perbedaan kebutuhan air untuk penduduk perkotaan dan pedesaan. Kebutuhan air penduduk perkotaan sebesar 120 liter/hari/kapita atau 43,8 $\mathrm{m}^{3} /$ kapita/tahun, dan kebutuhan air penduduk pedesaan sebesar 60 liter/hari/kapita atau $21,9 \mathrm{~m}^{3} / \mathrm{kapita} /$ tahun (Badan Standar Nasional Indonesia BSNI, 2002).

Untuk pengembangan kawasan perkotaan Sentul City yang dinamis dipandang perlu untuk mengetahui prediksi dan dinamika kebutuhan air dari masa ke masa, bahan keperluan perencanaan dan analisis yang berhubungan dengan kependudukan. Sehingga perlu untuk membuat model prediksi kebutuhan air bersih berdasarkan jumlah penduduk di kawasan perkotaan Sentul City pada saat ini dan di masa yang akan datang. Penelitian ini menyajikan analisis terhadap model prediksi kebutuhan air bersih berdasarkan jumlah penduduk dengan menggunakan bantuan perangkat lunak Stella 9.0.1

\section{TINJAUAN PUSTAKA}

\section{Metode Peramalan Populasi}

Banyak metode yang digunakan dalam memperkirakan laju perkembangan jumlah populasi. Metode perkiraan populasi dihitung dengan menggunakan 3 metode sebagai bahan perbandingannya. Ketiga metode tersebut antara lain adalah: (1). Metode Aritmatika; (2). Metode Geometri; dan (3). Metode Grafik dan Least Square.

\section{Metode Aritmatika}

Menurut McGhee (1991), metode aritmatika didasarkan pada anggapan bahwa laju perubahan populasi konstan, menggunakan asumsi bahwa pertumbuhan penduduk dengan jumlah sama setiap tahun. Bentuk matematis model aritmetik adalah sebagai berikut:

$$
\begin{aligned}
& P n \quad=P t+(K a * x) \\
& K a=\frac{(P t-P o)}{t}
\end{aligned}
$$

dengan:

Pn: Jumlah penduduk n pada tahun mndatang

Po: Jumlah penduduk pada awal tahun data

Pt: Jumlah penduduk pada akhir tahun data

$\mathrm{X}$ : Selang waktu (tahun dari tahun $\mathrm{n}-$ tahun terakhir)

T: Interval waktu tahun data (n-1)

\section{Metode Geometrik}

Metode ini dengan asumsi bahwa pertumbuhan penduduk yang menggunakan dasar bunga majemuk (Adioetomo dan Samosir, 2010). Angka pertumbuhan penduduk dianggap sama untuk setiap tahun, bentuk matematis model geometrik adalah sebagai berikut:

$Y n=P t(1+r)^{n}$ 
$r=\left(\frac{P t}{P o}\right)^{(1 / t)}-1$

dengan:

Yn: Jumlah penduduk pada tahun ke-n

Po:Jumlah penduduk pada awal tahun

Pt:Jumlah penduduk pada akhir tahun data

n:Interval waktu

r: Angka pertumbuhan penduduk (\%)

$\mathrm{t}$ : Interval waktu tahun data $(\mathrm{n}-1)$

\section{Metode grafik dan Least Square}

Metode grafik dipergunakan dengan cara memplotkan data populasi pada tahun sebelum perkiraan ke depan, kemudian dipilih grafik yang cenderung sesuai dengan pola perkembangan populasi. Setelah dipilih grafik yang sesuai, kemudian dapat diperkirakan populasi kedepan. Hal tersebut dilakukan dengan memperpanjang grafik tersebut (Al-Layla dan M. Anis, 1978).

Adapun bila dipilih bentuk geometri grafik yang sesuai, maka dapat dilakukan uji secara analitis dengan metode least square ini dapat diketahui tingkat korelasi antar kedua variable atau lebih, yang mana variable tersebut adalah jumlah populasi dengan waktu.

Metode least square merupakan metode regresi untuk mendapatkan hubungan antara sumbu $\mathrm{Y}$ dan sumbu $\mathrm{X}$ dimana $\mathrm{Y}$ adalah jumlah penduduk dan $\mathrm{X}$ adalah tahunnya dengan cara menarik garis linier antara data-data tersebut dan meminimumkan jumlah pangkat dua dari masing-masing penyimpangan jarak datadata dengan garis yang dibuat, bentuk matematis model least square adalah sebagai berikut:

$Y n=a+b$.

$$
\begin{aligned}
a & =\frac{\sum Y \cdot \sum X^{2}-\sum X \cdot \sum X Y}{n \sum X^{2}-\left(\sum X\right)^{2}} \\
b & =\frac{n \cdot \sum X Y-\sum X \cdot \sum Y}{n \cdot \sum X^{2}-\left(\sum X\right)^{2}}
\end{aligned}
$$

dengan:

Yn: Jumlah penduduk pada waktu $\mathrm{n}$ tahun mendatang

a: Konstanta

b: Koefisien laju pertambahan penduduk

$\mathrm{X}$ : Pertambahan tahun

n: Jumlah data

\section{Prediksi Kebutuhan Air}

Untuk mengetahui kebutuhan air di masa yang akan datang dibutuhkan jumlah penduduk di masa itu sendiri. Untuk mengetahui jumlah penduduk di masa yang akan datang sebagai faktor utama dalam perhitungan kebutuhan air menggunakan metode pendekatan geometrik yang telah direkomendasikan di dalam buku Pedoman Perencanaan Sumberdaya Air Wilayah Sungai yang telah diterbitkan Direktorat Jenderal Sumberdaya Air tahun 2001 (DJCK, 2001).

Menurut Adioetomo dan Samosir (2010), untuk memperoleh besaran jumlah kebutuhan air dalam satu wilayah digunakan persamaan yang merupakan perkalian antara jumlah penduduk dengan standar kebutuhan air.

Standar kelayakan kebutuhan air bersih adalah 49,5 liter/kapita/hari. Untuk kebutuhan tubuh manusia air yang diperlukan adalah 2,5 liter per hari. Standar kebutuhan air pada manusia biasanya mengikuti rumus $30 \mathrm{cc}$ per kilogram berat badan per hari. Artinya, jika seseorang dengan berat badan $60 \mathrm{~kg}$, maka kebutuhan air tiap harinya sebanyak $1.800 \mathrm{cc}$ atau 1,8 liter. Badan dunia UNESCO sendiri pada tahun 2002 telah menetapkan hak dasar manusia atas air yaitu sebesar 60 liter/orang/hari (UNESCO, 2002). Direktorat Jenderal Cipta Karya Departemen Pekerjaan Umum (DJCK, 2001) membagi lagi standar kebutuhan air minum tersebut berdasarkan lokasi wilayah sebagai berikut: 
a. Pedesaan dengan kebutuhan 60 liter/kapita/hari.

b. Kota Kecil dengan kebutuhan 90 liter/kapita/hari.

c. Kota Sedang dengan kebutuhan 110 liter/kapita/hari.

d. Kota Besar dengan kebutuhan 130 liter/kapita/hari.

e. Kota Metropolitan dengan kebutuhan 150 liter/kapita/hari.

Berdasarkan pada Peraturan Menteri Dalam Negeri Nomor 23 Tahun 2006 tentang Pedoman Teknis dan Tata Cara Pengaturan Tarif Air Minum pada Perusahaan Daerah Air Minum BAB I ketentuan umum Pasal 1 ayat 8 (MDN, 2006) menyatakan bahwa: "Standar Kebutuhan Pokok Air Minum adalah kebutuhan air sebesar 10 meter kubik/kepala keluarga/bulan atau 60 liter/orang/hari.

Kebutuhan air penduduk perkotaan sebesar 120 liter/hari/kapita atau 43,8 $\mathrm{m}^{3} /$ kapita/tahun, dan kebutuhan air penduduk pedesaan sebesar 60 liter/hari/kapita atau $21,9 \mathrm{~m}^{3} / \mathrm{kapita} /$ tahun (BSNI, 2002).

\section{Stella 9.0.1}

Stella adalah singkatan dari Systems Thinking, Experimental Learning Laboratory with Animation. Stella adalah software bahasa pemrograman visual (visual programming language) yg menggunakan prinsip model dinamis dengan berorientasi objek (Richmond, 1985). Program ini pertama kali didesain \& diperkenalkan oleh Barry Richmond pada tahun 1985 dan dikembangkan oleh isee systems. Stella memungkinkan pengguna untuk menjalankan model yang dibuat sebagai representasi grafis dari sistem menggunakan empat blok bangun dasar. Stella telah digunakan di dunia akademis sebagai alat pengajaran dan telah digunakan dalam berbagai aplikasi penelitian dan bisnis.

Aplikasi ini berguna untuk mendesain suatu kegiatan (penelitian, bahan ajar, bisnis, dan lain-lain) dalam bentuk gambar alur/flow chart sehingga mudah dipahami dan dapat dicari rancangan yang terbaik (Shiflet and Shiflet, 2006).

\section{Peramalan Populasi}

\section{METODOLOGI}

Peramalan jumlah penduduk dalam riset ini menggunakan pendekatan metode geometrik sebagaimana yang direkomendasikan pada buku Pedoman Perencanaan Sumberdaya Air Wilayah Sungai Direktorat Jenderal Sumberdaya Air tahun 2001. Sedangkan untuk mempermudah pemodelan, proyeksi jumlah penduduk, prediksi kebutuhan air bersih, dan menggambar grafik hubungan dinamika jumlah penduduk dengan kebutuhan air bersih digunakan software Stella 9.0.1.

\section{Prediksi kebutuhan air}

Untuk memprediksi jumlah kebutuhan air dalam satu wilayah digunakan persamaan yang merupakan perkalian antara jumlah penduduk dengan standar kebutuhan air. (Adioetomo dan Samosir, 2010). Berikut adalah persamaan umum yang digunakan dalam perhitungan:

$Q y=d y \times P y$

dimana:

$Q y:$ Kebutuhan air ( $\mathrm{m}^{3} /$ detik)

$d y:$ Standar kebutuhan

$P y$ : Jumlah pengguna

Kawasan perkotaan Sentul City dihuni oleh dua kelompok yaitu penduduk desa dan kota dengan standar kebutuhan air yang berbeda, adapun standar kebutuhan air penduduk perkotaan sebesar 120 liter/hari/kapita atau 43,8 
$\mathrm{m}^{3}$ /kapita/tahun, dan kebutuhan air penduduk pedesaan sebesar 60 liter/hari/kapita atau $21,9 \mathrm{~m}^{3} / \mathrm{kapita} /$ tahun (Badan Standar Nasional Indonesia BSI, 2002).
Untuk memudahkan analisis terhadap model prediksi kebutuhan air bersih berdasarkan jumlah penduduk dari masa ke masa, digunakan software Stella 9.0.1 dengan struktur model sebagaimana dapat dilihat pada Gambar 1.

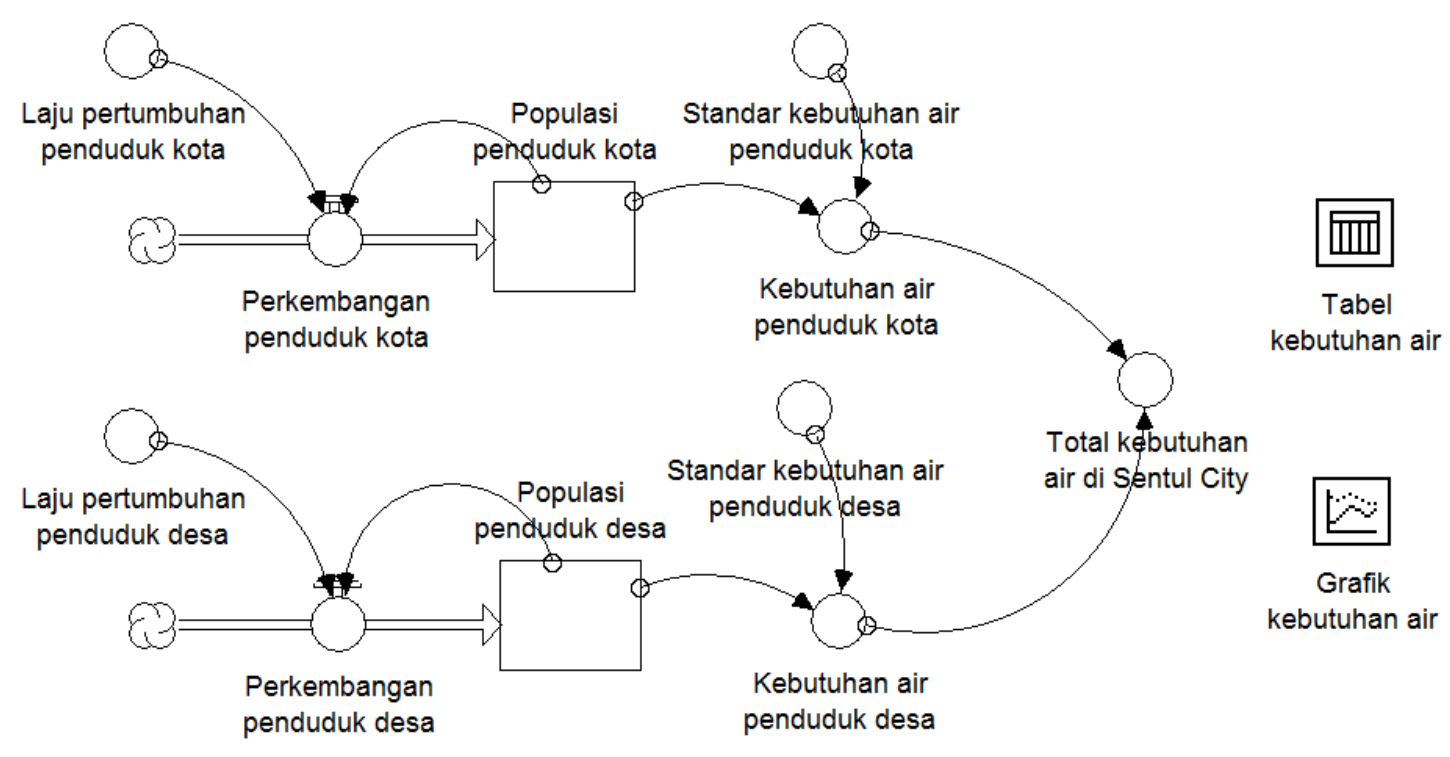

Gambar 1 Struktur model prediksi kebutuhan air di Sentul City

Pada struktur model prediksi kebutuhan air di Sentul city dibedakan kedalam 2 (dua) kategori karena berbeda karakteristik yaitu: (1). Kebutuhan air penduduk kota yang merupakan pendatang dari luar kawasan yang membeli hunian di Sentul City, bukan penduduk yang lahir dan tumbuh berkembang di Sentul City seperti penduduk desa di Sentul City, dan (2). Kebutuhan air penduduk desa yang telah bermukim lama secara turun temurun.

Penghuni kota Sentul City pada tahun 2018 telah mencapai kurang lebih 41.300 jiwa (SGC, 2018), dan target penghuni sampai dengan tahun 2050 sebanyak 40.000 kepala keluarga (KK). Apabila diasumsikan setiap KK terdiri atas 5 orang anggota, sehingga target penghuni sebesar 200.000 jiwa. Sentul City menargetkan penyelesaian pembangunan tahap pertama (2005-2025) seluas kurang lebih 50\% dari kawasan dan tahap kedua (2026-2050) sisanya. Pertumbuhan penduduk kota di Sentul City dihitung dengan asumsi pertumbuhan penduduk adalah linear, dengan target pada tahun 2050 dihuni oleh 200.000 penduduk. Dengan demikian, pertumbuhan penduduk dari tahun 2018 hingga 2050 diasumsikan tetap, yaitu 4.960 jiwa per tahun., maka jumlah penduduk kota yang dihitung dengan metode aritmatik diperkirakan pada tahun 2025 adalah 76.020 jiwa dan pada tahun 2050 adalah 228.743 jiwa.

Kondisi awal penduduk di kawasan Sentul City pada tahun 2018 adalah sebanyak 88.005 jiwa. Laju pertumbuhan penduduk desa di Sentul City adalah sebesar 3,03\%. (BPS Kabupaten Bogor 2016). Berdasarkan rumus laju pertumbuhan penduduk metode geometrik diperkirakan jumlah penduduk desa pada tahun 2025 adalah 108.457 jiwa dan pada tahun 2050 adalah 200.020 jiwa. 
HASIL DAN PEMBAHASAN

\section{Letak Geografis dan Administras Pemerintahan}

Secara geografis Sentul City terletak pada koordinat $06^{\circ} 33^{\prime} 55^{\prime \prime}-06^{\circ} 37^{\prime} 45^{\prime \prime}$ LS dan 106 $50^{\prime} 20^{\prime \prime}$ - 106 $57^{\prime} 10^{\prime \prime}$ BT. Luas kawasan Sentul City yang tertulis di Masterplan Sentul City Tahun 2011 adalah sebesar 2.465 ha yang terletak pada batasan kawasan seluas 3.001,4 ha. Namun, pada kajian ini dilakukan analisis spasial dengan luas 2.905,33 ha sesuai garis batas kawasan dalam bentuk vektor yang didapatkan dari pihak perencana kota.

Secara administrasi pemerintahan, Sentul City berada pada 8 Desa dan 2 Kecamatan, meliputi: Desa Cipambuan, Desa Babakan Madang, Desa Citaringgul, Desa Bojong Koneng, Desa Sumur Batu, Desa Cijayanti, Desa Kadumanggu, dan Desa Cadas Ngampar. Kecamatannya yaitu Kecamatan Babakan Madang dan Kecamatan Sukaraja, Kabupaten Bogor. Batas wilayah Sentul City adalah sebagai berikut:

Utara : Desa Cipambuan dan Desa Kadungmanggu.
Selatan : Desa Nanggrak dan Desa Cijayanti.

Barat : Desa Cijayanti, Desa Cikeas, dan Desa Cadas Ngampar.

Timur : Desa Hambalang dan Desa Karang Tengah

Cluster BGH berada di Desa Cijayanti. Cluster ini memiliki Gross Area sekitar $884.545 \mathrm{~m}^{2}$ (88,5 ha). Area disini dibagi menjadi 2 macam, Efektif Area dan Non Efektif Area. Efektif Area terdiri dari luas kavling $\left(541,131 \mathrm{~m}^{2}\right)$ dan KDB $\left(295,385 \mathrm{~m}^{2}, 33.39 \%\right)$. Non Efektif Area terdiri dari luas hijau, fasilitas umum/sosial (242,240 m2), luas jalan dan saluran $\left(101,174 \mathrm{~m}^{2}\right)$, dan $\mathrm{KDB}(82,241$ $\left.\mathrm{m}^{2}, 9.3 \%\right)$.

\section{Penduduk}

Secara umum permukiman penduduk yang berada di kecamatan Sukaraja, Babakan Madang, dan Citeureup terbagi atas dua kategori permukiman yaitu permukiman yang terencana tumbuh dan permukiman yang tidak terencana. Kondisi penduduk di setiap desa dapat dilihat pada Tabel 1.

Tabel 1 Kondisi penduduk di Setiap Desa Tahun 2017

\begin{tabular}{|c|c|c|c|c|}
\hline No. & $\begin{array}{l}\text { Nama } \\
\text { Desa/Kecamatan }\end{array}$ & Luas $\left(\mathbf{m}^{2}\right)$ & $\begin{array}{l}\text { Luas Desa } \\
\text { (ha) }\end{array}$ & $\begin{array}{l}\text { Jumlah } \\
\text { (jiwa) }\end{array}$ \\
\hline & $\begin{array}{l}\text { Kecamatan Babakan } \\
\text { Madang }\end{array}$ & & & \\
\hline 1. & Cipambuan & 92,46 & 201 & 5.573 \\
\hline 2. & Babakan Madang & & 233 & 12.719 \\
\hline 3. & Citaringgul & 275 & 345 & 10.505 \\
\hline 4. & Bojong Koneng & $1.057,49$ & 2.441 & 14.268 \\
\hline 5. & Sumur Batu & 519 & 484 & 9.474 \\
\hline 6. & Cijayanti & 624,53 & 2.551 & 18.536 \\
\hline \multirow[t]{2}{*}{7.} & Kadumanggu & 3 & 410 & 18.563 \\
\hline & Kecamatan Suka & & & \\
\hline \multirow[t]{2}{*}{0} & Cadas Nga & 53,83 & 183 & 8.238 \\
\hline & TOTAL & $2.905,33$ & 6.848 & 97.876 \\
\hline
\end{tabular}

Sumber: BPS Kabupaten Bogor, 2017.

Permukiman yang terencana tumbuh dalam dua sampai tiga dekade terakhir dibangun dalam skala menengah dan besar untuk masyarakat berpendapatan menengah dan menengah ke atas. Permukiman yang tidak terencana berupa 
pola perkampungan terdapat di dalam kawasan Sentul City dan sekitarnya yang berbentuk memanjang, terapit, dan mengikuti jalur jalan, serta lembah atau

\section{Analisis Kebutuhan air}

Pada tahun 2018 jumlah penduduk desa di kawasan Sentul City sebanyak 88.005 jiwa. Berdasarkan rumus laju pertumbuhan penduduk, dilakukan penghitungan jumlah penduduk desa yang ada di kawasan Sentul City. Hasil perhitungan menunjukkan bahwa laju pertumbuhan penduduk desa di Sentul City adalah sebesar 3,03\%. Laju pertumbuhan ini lebih besar dibandingkan laju pertumbuhan penduduk Kabupaten Bogor yaitu sebesar 2.39\% Kabupaten Bogor (2016). Sesuai nilai laju pertumbuhan tersebut, diperkirakan jumlah penduduk desa pada tahun 2025 adalah 108.528 jiwa dan pada tahun 2050 mencapai 229.452 jiwa.

Penghuni kota Sentul City telah mencapai kurang lebih 41.300 jiwa (PT. Sukaputra Graha Cemerlang, 2018). Penduduk kota ini merupakan pendatang dari luar kawasan yang membeli hunian di Sentul City, bukan penduduk yang lahir dan tumbuh berkembang di Sentul City seperti penduduk desa di Sentul City. Sentul City memiliki target penghuni sebanyak 40.000 kepala keluarga (KK). Dengan demikian, target penghuni adalah 200.000 jiwa dengan asumsi setiap kepala keluarga terdiri atas 5 orang anggota. Sentul City menargetkan penyelesaian pembangunan tahap pertama seluas kurang lebih $50 \%$ dari kawasan pada tahun 2025. Dengan bukit dibelakangnya dengan keberadaan toko dan usaha perdagangan penduduk setempat.

demikian, diasumsikan pembangunan keseluruhan dapat terselesaikan pada tahun 2050 dan penghuni kota telah menetap di Sentul City dengan penambahan hunian 992 unit per tahun atau 4.960 jiwa per tahun.

Dengan diketahui laju pertumbuhan pengguna dan proyeksi jumlah pengguna, dapat dihitung kebutuhan air untuk penduduk daerah perkotaan dan pedesaan yang ada di Sentul City. Terdapat perbedaan kebutuhan air antara penduduk perkotaan dan pedesaan. Kebutuhan air untuk penduduk perkotaan adalah sebesar 120 liter/hari/kapita, sedangkan kebutuhan air untuk penduduk pedesaan adalah sebesar 60 liter/hari/kapita (BSNI 2002).

Dengan menggunakan software Stella 9.0.1, dengan input data jumlah penduduk desa dan laju pertumbuhan penduduk maka jumlah penduduk desa tiap tahun dan grafik pertumbuhan penduduk dapat ditentukan, dan dengan input data jumlah penduduk kota dan laju penambahan bangunan pemukiman maka jumlah penduduk kota tiap tahun dan grafik pertumbuhan penduduk dapat ditentukan. Kenaikan jumlah penduduk desa, kota, dan kebutuhan air di Sentul City tahun 2018 - 2050 dapat dilihat pada Tabel 2. Sedangkan grafik hubungan kenaikan jumlah penduduk desa, kota, dan kebutuhan air di Sentul City tahun 2018 2050 dapat dilihat pada Gambar 2 dan persamaan prediksi kebutuhan air di Sentul City disajikan pada Gambar 3. 
Tabel 2 Kenaikan jumlah penduduk desa, kota, dan kebutuhan air di Sentul City tahun $2018-2050$.

\begin{tabular}{|c|c|c|c|c|c|}
\hline \multirow{2}{*}{ Tahun } & \multicolumn{2}{|c|}{ Populasi penduduk } & \multicolumn{2}{|c|}{ Kebutuhan air penduduk } & \multirow{2}{*}{ Total kebutuhan air } \\
\hline & Desa & Kota & Desa & Kota & \\
\hline 2018 & 88,005 & 41,300 & $1,808,940$ & $1,927,309$ & $3,736,249$ \\
\hline 2019 & 90,672 & 46,260 & $2,026,188$ & $1,985,717$ & $4,011,905$ \\
\hline 2020 & 93,419 & 51,220 & $2,243,436$ & $2,045,876$ & $4,289,312$ \\
\hline 2021 & 96,250 & 56,180 & $2,460,684$ & $2,107,875$ & $4,568,559$ \\
\hline 2022 & 99,166 & 61,140 & $2,677,932$ & $2,171,735$ & $4,849,667$ \\
\hline 2023 & 102,171 & 66,100 & $2,895,180$ & $2,237,545$ & $5,132,725$ \\
\hline 2024 & 105,267 & 71,060 & $3,112,428$ & $2,305,347$ & $5,417,775$ \\
\hline 2025 & 108,457 & 76,020 & $3,329,676$ & $2,375,208$ & $5,704,884$ \\
\hline 2026 & 111,743 & 80,980 & $3,546,924$ & $2,447,172$ & $5,994,096$ \\
\hline 2027 & 115,129 & 85,940 & $3,764,172$ & $2,521,325$ & $6,285,497$ \\
\hline 2028 & 118,617 & 90,900 & $3,981,420$ & $2,597,712$ & $6,579,132$ \\
\hline 2029 & 122,211 & 95,860 & $4,198,668$ & $2,676,421$ & $6,875,089$ \\
\hline 2030 & 125,914 & 100,820 & $4,415,916$ & $2,757,517$ & $7,173,433$ \\
\hline 2031 & 129,729 & 105,780 & $4,633,164$ & $2,841,065$ & $7,474,229$ \\
\hline 2032 & 133,660 & 110,740 & $4,850,412$ & $2,927,154$ & $7,777,566$ \\
\hline 2033 & 137,710 & 115,700 & $5,067,660$ & $3,015,849$ & $8,083,509$ \\
\hline 2034 & 141,883 & 120,660 & $5,284,908$ & $3,107,238$ & $8,392,146$ \\
\hline 2035 & 146,182 & 125,620 & $5,502,156$ & $3,201,386$ & $8,703,542$ \\
\hline 2036 & 150,611 & 130,580 & $5,719,404$ & $3,298,381$ & $9,017,785$ \\
\hline 2037 & 155,175 & 135,540 & $5,936,652$ & $3,398,333$ & $9,334,985$ \\
\hline 2038 & 159,877 & 140,500 & $6,153,900$ & $3,501,306$ & $9,655,206$ \\
\hline 2039 & 164,721 & 145,460 & $6,371,148$ & $3,607,390$ & $9,978,538$ \\
\hline 2040 & 169,712 & 150,420 & $6,588,396$ & $3,716,693$ & $10,305,089$ \\
\hline 2041 & 174,854 & 155,380 & $6,805,644$ & $3,829,303$ & $10,634,947$ \\
\hline 2042 & 180,152 & 160,340 & $7,022,892$ & $3,945,329$ & $10,968,221$ \\
\hline 2043 & 185,611 & 165,300 & $7,240,140$ & $4,064,881$ & $11,305,021$ \\
\hline 2044 & 191,235 & 170,260 & $7,457,388$ & $4,188,046$ & $11,645,434$ \\
\hline 2045 & 197,029 & 175,220 & $7,674,636$ & $4,314,935$ & $11,989,571$ \\
\hline 2046 & 202,999 & 180,180 & $7,891,884$ & $4,445,678$ & $12,337,562$ \\
\hline 2047 & 209,150 & 185,140 & $8,109,132$ & $4,580,385$ & $12,689,517$ \\
\hline 2048 & 215,487 & 190,100 & $8,326,380$ & $4,719,165$ & $13,045,545$ \\
\hline 2049 & 222,016 & 195,060 & $8,543,628$ & $4,862,150$ & $13,405,778$ \\
\hline 2050 & 228,743 & 200,020 & $8,760,876$ & $5,009,472$ & $13,770,348$ \\
\hline
\end{tabular}

Sumber: Hasil analisis data dengan software Stella 9.0.1 (2019) dalam formt excel. 


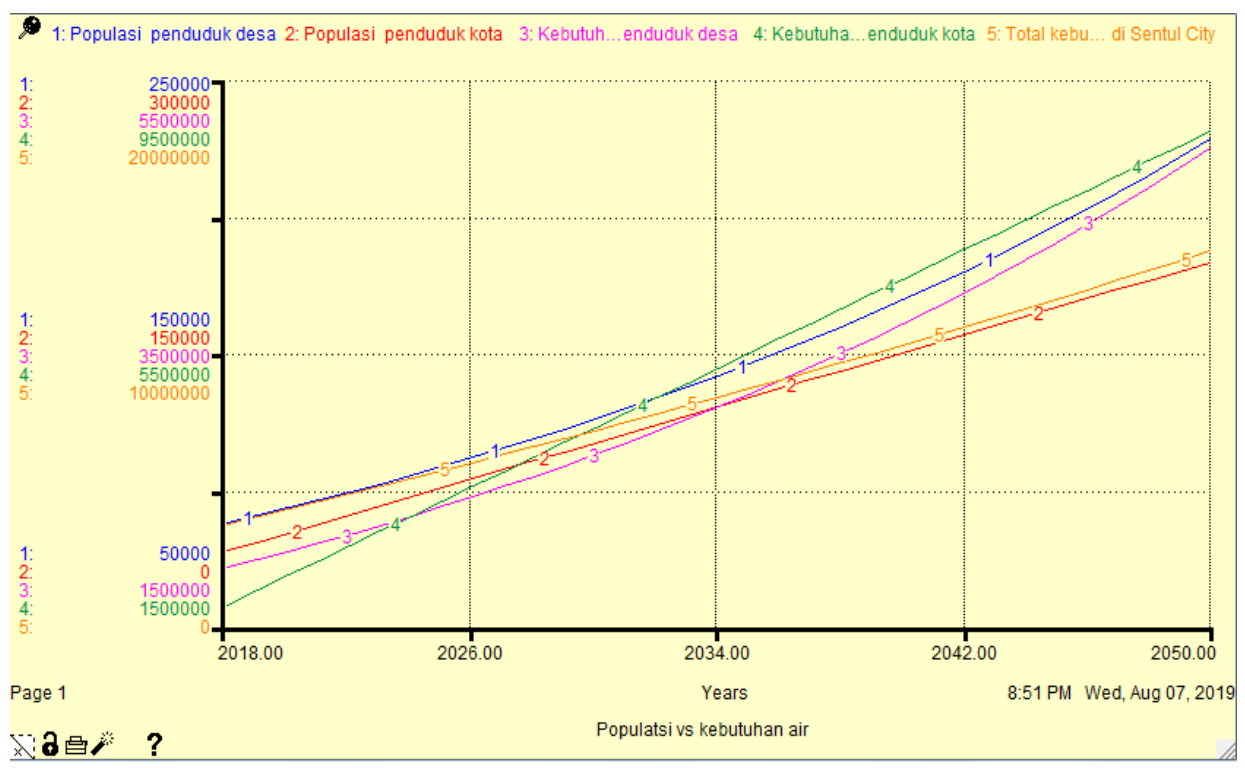

Gambar 2 Grafik hubungan kenaikan jumlah penduduk desa, kota, dan kebutuhan air di Sentul City tahun 2018 - 2050 dengan Stella 9.0.1.

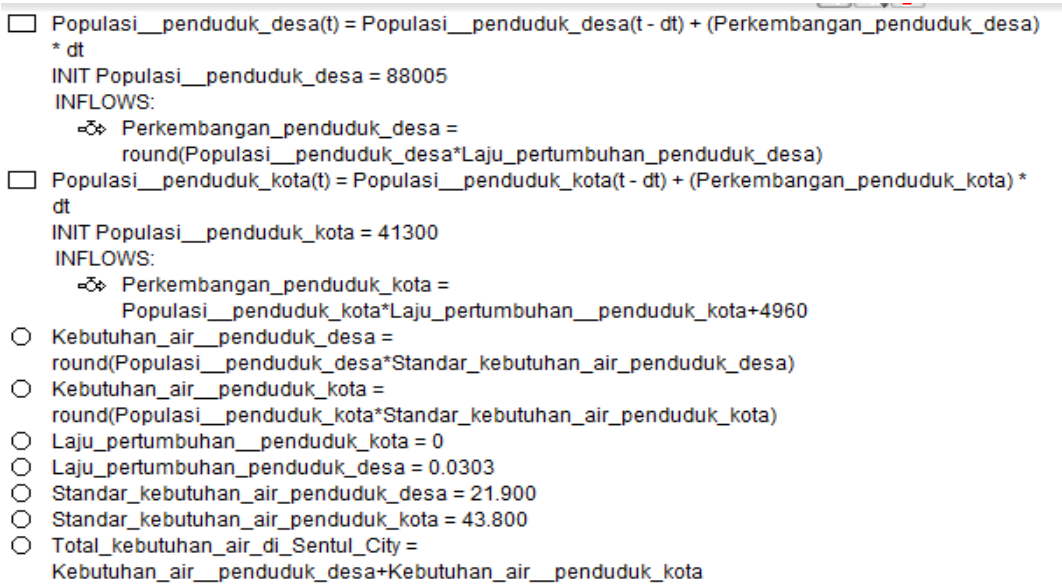

Gambar 3 Persamaan prediksi kebutuhan air di Sentul City dengan Stella 9.0.1

Berdasarkan hasil proyeksi, diperkirakan pada tahun 2025 jumlah penduduk kota dan desa adalah sebanyak 76.020 dan 108.529 dengan total 184.549 jiwa. Dengan jumlah penduduk tersebut, dilakukan proyeksi terhadap kebutuhan air domestik dan nondomestik. Proyeksi kebutuhan air di Sentul City dihitung dengan asumsi konsumsi air penduduk kota sebesar 120 liter/hari, konsumsi air penduduk desa 60 liter/hari. Total kebutuhan air penduduk di kawasan Sentul City pada tahun 2025 diproyeksikan mencapai 5.706 .462 $\mathrm{m}^{3} /$ tahun dan pada tahun 2050 sebesar $13.785 .875 \mathrm{~m}^{3} /$ tahun.

\section{Masterplan Sentul City}

Rencana penggunaan lahan di Kawasan Sentul City tertuang pada rencana induk atau masterplan Sentul City. Area yang direncanakan sebagai lahan terbangun adalah sebesar 2.420 ha atau $83.62 \%$. Secara tekstual rencana induk penggunaan lahan disajikan pada Tabel 3 dan secara grafis disajikan pada Gambar 4. 


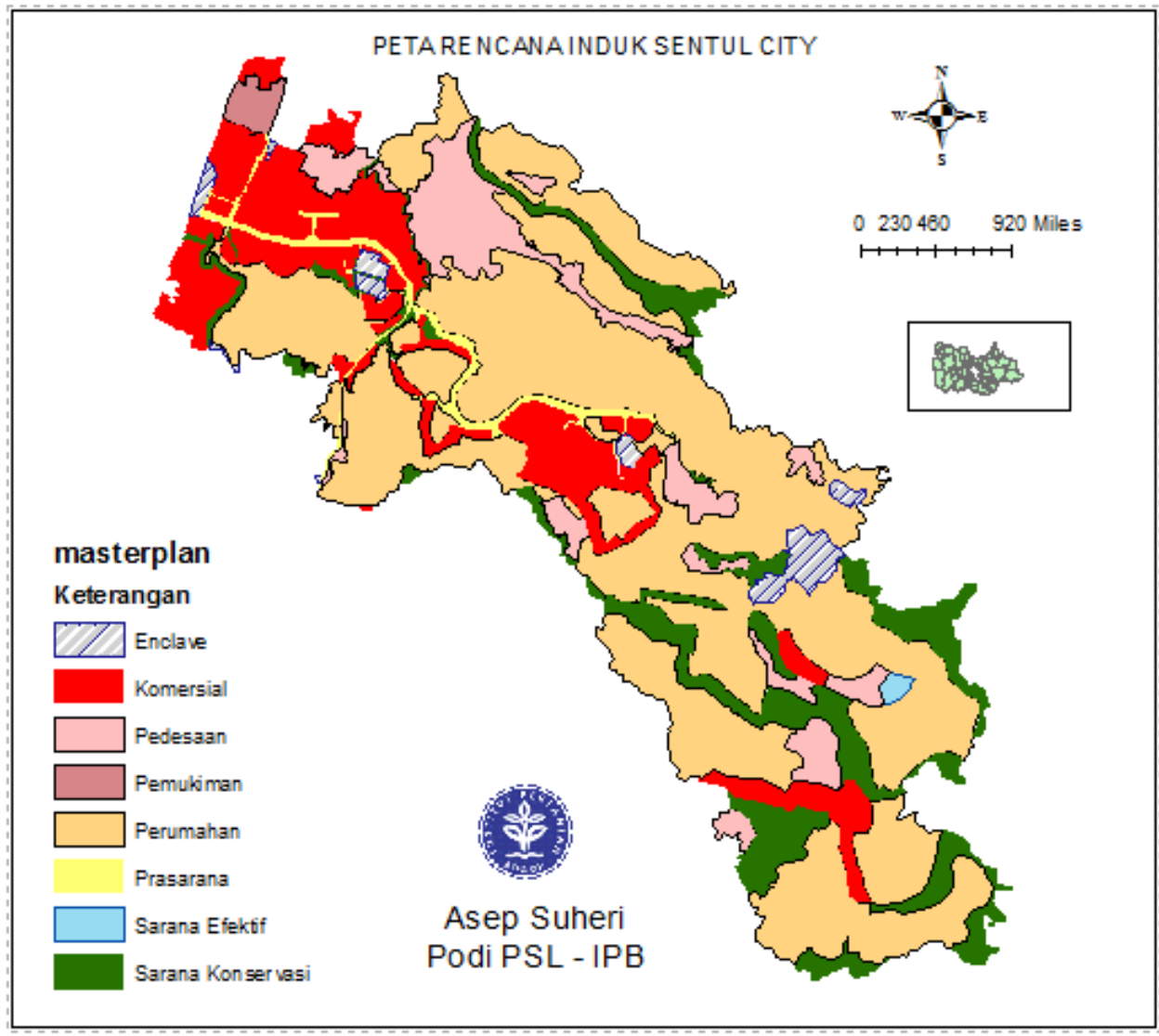

Gambar 4 Masterplan Sentul City (2011)

Rencana pembangunan pada tahun 2015-2025 terbagi menjadi lima zona dengan total area pengembangan $335.6 \mathrm{ha}$, yang terdiri atas area efektif bangunan sebesar 50\%, dan jalan serta RTH sebesar $50 \%$.

Tabel 3 Rencana Penggunaan Lahan

\begin{tabular}{|c|c|c|c|}
\hline \multirow{2}{*}{ No. } & \multirow{2}{*}{ Jenis Penggunaan Lahan } & \multicolumn{2}{|c|}{ Luas } \\
\hline & & Ha & Prosen (\%) \\
\hline 1 & Enclave & 63,20 & 2,18 \\
\hline 2 & Komersial & 459,35 & 15,81 \\
\hline 3 & Pedesaan & 277,37 & 9,55 \\
\hline 4 & Pemukiman & 23,18 & 0,80 \\
\hline 5 & Perumahan & $1.638,19$ & 56,38 \\
\hline 6 & Prasarana & 61,40 & 2,12 \\
\hline 7 & Sarana efektif & 6,56 & 0,23 \\
\hline 8 & Sarana konservasi & 376,08 & 12,94 \\
\hline Total & & $2.905,33$ & 100,00 \\
\hline
\end{tabular}

Sumber: Masterplan Sentul City, 2011.

Pembangunan yang telah selesai adalah beberapa perkantoran dan komersial seperti Marketing Gallery Office, Bellanova Mall, Sentul International Convention Center, Giant Extra Supermarket, CBD Niaga, Pasar Bersih, Taman Budaya dan Neo Green Savana
Hotel, Rumah Sakit Pertamedika, BCA Training Center, perumahan pada beberapa cluster, area peribadatan seperti Masjid Andalusia, dan sekolah seperti STEI Tazkia, Sekolah Terpadu Fajar Hidayah, dan beberapa fasilitas seperti pusat rehabilitasi. 


\section{KESIMPULAN}

Berdasarkan hasil analsis, diperoleh persamaan prediksi kebutuhan air bersih ( $\mathrm{m}^{3} /$ tahun) di Sentul City untuk penduduk desa: YDn $=1.927 .309(1+0.0303)^{\mathrm{n}}$; penduduk kota: YKn $=1.808 .940+$ $217.248^{*} \mathrm{n}$; dan penduduk keseluruhan: $\mathrm{YSCn}=\mathrm{YDn}+\mathrm{YKn}$.

Hasil proyeksi kebutuhan air di wilayah kajian pada tahun 2019 sebesar 4.012.080 $\mathrm{m}^{3} /$ tahun; tahun 2025 sebesar $5.706 .461 \mathrm{~m}^{3} /$ tahun; tahun 2030 sebesar $7.176 .608 \mathrm{~m}^{3} /$ tahun; tahun 2040 sebesar 10.312.995 $\mathrm{m}^{3} /$ tahun; dan tahun 2050 sebesar $13.785 .875 \mathrm{~m}^{3} /$ tahun. Kebutuhan air meningkat 3,7 kali dalam jangka waktu 32 tahun.

Untuk meningkatkan keakurasian dan ketepatan model prediksi kebutuhan air bersih berdasarkan jumlah penduduk di kawasan perkotaan Sentul City dari tahun ke tahun, harus didukung dengan data kependudukan dari instansi terkait pada tahun tersebut.

\section{DAFTAR PUSTAKA}

Adioetomo SM dan Samosir OB. 2010. Dasar-dasar Demografi edisi 2. Jakarta:Penerbit Salemba Empat.

Al-Layla dan M. Anis. 1978. Water Supply Engineering Design. Dean. College of Engineering University of Mosul: Iraq

Angela B. Shiflet and George W. Shiflet. 2006. System Dynamics Tool: STELLA Version 9 Tutorial 2. Introduction to Computational Science: Modeling and Simulation for the Sciences. Princeton University Press.

[BPS] Badan Pusat Statistik Kabupaten Bogor (ID). 2015. Kecamatan Babakan Madang dalam Angka (2015). Bogor (ID): Badan Pusat Statistik Kabupaten Bogor.
[BPS] Badan Pusat Statistik Kabupaten Bogor (ID). 2016. Kabupaten Bogor dalam Angka (2016). Bogor (ID): Badan Pusat Statistik Kabupaten Bogor.

[BPS] Badan Pusat Statistik Kabupaten Bogor (ID). 2017. Kecamatan Babakan Madang dalam Angka (2017). Bogor (ID): Badan Pusat Statistik Kabupaten Bogor.

[BSNI] Badan Standardisasi Nasional (ID). 2002. Standar Nasional Indonesia: Penyusunan Neraca Sumber Daya -Bagian 1 Sumber Daya Air Spasial [Internet]. [diunduh 2017 Agustus 27]. Tersedia pada: www.bakosurtanal.go.id/assets/ download/sni/SNI/SNI\%20196728.1-2002.pdf.

Barry M. Richmond. 1985. Introduction to Systems Thinking, STELLA. High Performance Systems, Inc. All rights reserved.

Coyle, R. 1996. Systems Dynamic Modelling. London: Chapman\&Hal.

[DJCK] Direktorat Jenderal Cipta Karya. 2001. Pedoman Perencanaan Sumberdaya Air Wilayah Sungai. Departemen Pekerjaan Umum, Jakarta.

[DPAM] Direktorat Pengembangan Air Minum. 2006. Dialog Penajaman Pola Konsumsi dan Kebutuhan Pokok Minimal Nasional. Ditjen Cipta karya, Departemen Pekerjaan Umum, Jakarta

[FAO] Food and Agriculture Organization of the United Nations (US). 1976. A Framework for Land Evaluation. FAO Soil Bulletin No. 32. Roma (US): FAO Soil Resources Management and Conservation Service Land and Water Development Division. 
[FAO] Food and Agriculture Organization of the United Nations (US). 1983. Reconnaissance Land Resource Survey 1:250 000 scale. Atlas Format Procesures. Land Resources Evaluation with Emphasis on Outer Island Project. CSR/FAP Indonesia AGOFANS/78/006. Mannual 4 Version 1.

Kodoatie RJ, Sjarief R. 2008. Pengelolaan Sumber Daya Air Terpadu (Edisi Revisi). Yogyakarta (ID): Andi.

McGhee, Terence J. 1991. Water Supply and Sewerage. MCGraw-hill, Inc.

[MDN] Menteri Dalam Negeri. 2006. Permendagri No.23 Tahun 2006 tentang Pedoman Teknis dan Tata Cara Pengaturan Tarif Air Minum pada Perusahaan Daerah Air Minum. Departemen Dalam Negeri, Jakarta.

Muhammadi, Aminullah, E., \& Soesilo, B. 2001. Analisis Sistem Dinamis: Lingkungan Hidup, Sosial, Ekonomi, Manajemen. Jakarta: UMJ Press.

Sentul City (ID). 2011. Masterplan 2465 Ha Sentul City (Revisi). Bogor (ID): PT Sentul City Tbk.

Sentul City (ID). 2012. Sentul City Green Development. Bogor (ID): PT Sentul City Tbk.

Sentul City (ID). 2014. Sentul City Development 2015-2025. Bogor (ID): PT Sentul City Tbk.

Sterman, J. 2000. Business Dynamics: System\ Thinking and Modelling for a Complex World. Chicago, IL: Irwin-McGraw-Hill.

Sterman, J. D. 2000. Bussines Dynamic. USA: Massachussets Institute of Technologies.

Sterman, J., Henderson, R., Beinhocker, E., \& Newman, L. 2007. Getting big too fast:strategic dynamics with increasing returns and bounded rationally. Management Science, 53(4), 683-696.

[SGC] Sukaputra Grahacemerlang (ID). 2013. Cityzen: Sentul City Free Magazine. Edisi November 2013. Bogor (ID): PT Sentul City Tbk.

[SGC] Sukaputra Grahacemerlang (ID). 2017. Cityzen: Sentul City Free Magazine. Edisi November 2017. Bogor (ID): PT Sentul City Tbk.

[SGC] Sukaputra Grahacemerlang (ID). 2018. Cityzen: Sentul City Free Magazine. Edisi November 2018. Bogor (ID): PT Sentul City Tbk.

[UNESCO] United Nations of Educational, Scientific, and Cultural Organization. 2002. The UN Committee on Economic, Social and Cultural Rights adopted its general comment No. 15 on the right to water stating. 